\title{
INVERTEBRATES INHABITING CULINARY HERBS GROWN UNDER COVER
}

\author{
Magdalena Lubiarz ${ }^{1 *}$, Wojciech Goszczyński², Elżbieta Cichocka ${ }^{3}$ \\ 1,3 Department of Environmental Protection and Landscape Preservation \\ ${ }^{2}$ Department for Natural Foundations of Landscape Architecture \\ The John Paul II Catholic University of Lublin, Al. Racławickie 14, 20-950 Lublin, Poland
}

Received: June 6, 2013

Accepted: September 30, 2013

\begin{abstract}
The study contains the list of invertebrates collected from culinary herbs (Allium schoenoprasum, Anethum graveolens, Anthriscus sp., Petroselinum crispum, Coriandrum sativum, Artemisia dracunculus, Eruca sativa, Melissa officinalis, Mentha arvensis, Mentha xpiperita, Ocimum basilicum, Origanum majorana, Origanum vulgare, Salvia officinalis, Thymus vulgaris, Rosmarinus sp.) in greenhouses, under plastic-film covers, and at mother farms. The study provides information about the times of the year when these invertebrates settle on the herbs, and about the specific character of cultivating such plants. Even a few individual arthropods on culinary herbs cannot be tolerated and eliminating arthropods by using chemicals is unacceptable. For these reasons, those plants on which the arthropods have settled must be removed from greenhouses and destroyed. Biological pest control is also recommended. Some species of the observed invertebrates are encountered in a greenhouse year-round (Myzus persicae, Aphis gossypii, Ovatus mentharius, Aulacorthum solani, Eupteryx sp., Trialeurodes vaporariorun, larvae of Thysanoptera) while others appear only during the periods of spring migrations (Cavariella aegopodi) or autumn migrations (Aphis fabae, Dysaphis crataegii, butterflies from the subfamily Hadeninae). Peppermint had already been inhabited by $O$. mentharius on mother farms, and $O$. mentharius probably hibernated on farms as well. Potted peppermint seedlings brought from mother farms to greenhouses had already been inhabited by that aphid species. Some invertebrates were associated with a substrate (Sciaridae) while the appearance of others coincided with the development of algae (Ephydridae: Scatella sp.).
\end{abstract}

Key words: culinary herbs, greenhouses, insects and other animals

\section{INTRODUCTION}

Wide-scale cultivation of culinary herbs in Poland has recently begun. More and more such cultivations are being established throughout the country. Presently, culinary herbs can be bought in small plastic pots in most large grocery stores. The fauna of those plants has not been studied so far. Various species of invertebrates occur on culinary herbs and contaminate them. The producers have to remove the inhabited plants, since no buyer wants culinary herbs with aphids or snails. However, it is possible to use methods of biological pest control in culinary herb cultivation.

Culinary herbs cultivated in greenhouses were placed on movable cultivation gutters. Rosemary, peppermint, and field mint were propagated from seedlings collected from mother farms. Chives were sown in pots on the field and left in the open until the first ground frost of the season. After the first frost, the pots were taken to a freezer, and then systematically, as the need arises, put into plastic pots and brought to a greenhouse. The remaining $\mathrm{cu}-$ linary herbs were sown directly into pots and put on the gutters.

On such gutters, contrary to other greenhouse cultivations, the time of growth is very short. Only rosemary and mint last for about 8 weeks. The other herbs last between 3 and 4 weeks. During that short period the invertebrates do not usually become very numerous and inhabit about $10 \%$ of the herbs at the most. Only during the periods of aphid migrations in the spring and in the autumn, have more numerous appearances of those insects been observed. However, regardless of the number, the plants on which the insects have settled have to be destroyed, which generates serious losses. For instance, during the first quarter of 2013, out of 70 thousand pots of basil, 3 thousand had to be destroyed, i.e. as much as $2.3 \%$ of the total number of plants.

\section{MATERIAL AND METHODS}

The research was conducted in 2010-2012 in the surroundings of Warsaw, Poland, and during the first quarter of 2013 in a nearly 2 ha production greenhouse designed especially for cultivating culinary herbs, and under two plastic-film covers with a total area of about $800 \mathrm{~m}^{2}$. Apart from that, mother farm fields of peppermint, garden mint, and rosemary were monitored during a one-year period. Production of mother plantings was also established in greenhouses but situated at considerable distances from 
the culinary herb cultivations. The research encompassed 16 species of culinary herbs, representing 5 families:

- Amaryllidaceae: chives (Allium schoenoprasum L.);

- Apiaceae: dill (Anethum graveolens L.), chervil (Anthriscus sp.), parsley (Petroselinum crispum (Mill.) Fuss), coriander (Coriandrum sativum L.);

- Asteraceae: tarragon (Artemisia dracunculus L.);

- Brassicaceae: salad rocket (Eruca sativa Mill.);

- Lamiaceae: lemon balm (Melissa officinalis L.), field mint (Mentha arvensis L.), peppermint (Mentha xpiperita L.), basil (Ocimum basilicum L.), marjoram (Origanum majorana L.), oregano (Origanum vulgare L.), sage (Salvia officinalis L.), thyme (Thymus vulgaris L.), rosemary (Rosmarinus sp.).

The present research has a preliminary character. All plant pots for sale (about 500 pieces) were placed on gutters and inspected every 6-7 days. The plants on which insects had settled were selected and the species that inhabited them were identified. The mother plantings of peppermint, and garden mint as well as rosemary were inspected every 14 days for one year. Apart from that, yellow sticky boards were hung out in greenhouses to monitor the appearance of particular species in the investigated culinary herb cultivations. Collected animals were identified with respect to their species or at least orders. In the case of snails, however, such an identification was not always possible, since only very small young specimens were found. Names of invertebrates were given after Fauna Europaea (2012).

\section{RESULTS AND DISCUSSION}

The representatives of the following groups of invertebrates were found on the studied plants: Thysanoptera, Hemiptera (Aphididae, Aleyrodidae and Cicadellidae), Lepidoptera (Noctuidae: Hadeninae), and Diptera (Sciaridae). Scatella stagnalis (Fallen 1823) from the family Ephydridae was found on the algae that sometimes appeared as well. That particular fly species caused problems for the people working in the greenhouse because it caused eye irritation. Slugs and snails were observed in mother plantings of rosemary and peppermint. However, not all of the studied plants were inhabited by invertebrates. The list of invertebrates inhabiting culinary herbs is shown in table 1.

\section{A review of the invertebrates found on the culinary herbs}

\section{The Thysanoptera}

Characteristic lesions, which were not very numerous, were found on A. schoenoprasum, M. xpiperita, O. basilicum, and Rosmarinus sp. Adult thrip specimens were found on yellow sticky boards. No second stage larvae were found on the plants that would make it possible to identify the species. On a single occasion in 2013, several thrip larvae (first stage) were found on basil and on peppermint. It is probable that the source from which those insects originated was the chives brought from the field and put into the freezer, to be

Table 1. The list of invertebrates inhabiting culinary herbs

Culinary herbs

\begin{tabular}{|c|c|c|c|c|c|c|c|c|c|c|}
\hline \multirow[b]{2}{*}{ Invertebrates } & & & & & & & & & & \\
\hline & 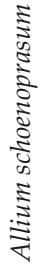 & 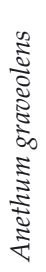 & 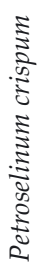 & 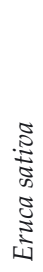 & 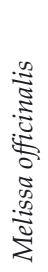 & 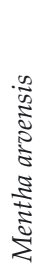 & 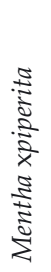 & 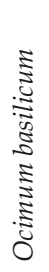 & 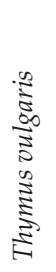 & 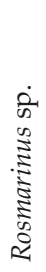 \\
\hline Larva of Thysanoptera & + & - & - & - & - & - & + & + & - & + \\
\hline Trialeurodes vaporariorum & - & - & - & - & - & - & - & - & - & + \\
\hline Eupteryx sp. & - & - & - & - & + & + & + & - & - & + \\
\hline Aphis gossypii & - & - & + & - & - & - & - & - & - & + \\
\hline Aphis fabae & - & - & + & - & - & - & - & - & - & - \\
\hline Aulacorthum solani & - & - & - & - & - & - & - & + & - & - \\
\hline Cavariella aegopodii & - & + & - & - & - & - & - & - & - & - \\
\hline Dysaphis crataegi & - & - & + & - & - & - & - & - & - & - \\
\hline Myzus persicae & - & - & - & + & - & - & + & + & - & - \\
\hline Ovatus mentharius & - & - & - & - & - & - & + & - & - & - \\
\hline Larva of Hadeninae & - & - & - & - & - & + & + & + & - & - \\
\hline Larva of Agrotis sp. & + & - & - & - & - & - & - & - & - & - \\
\hline Larva of Sciaridae [in soil] & + & + & + & + & + & + & + & + & + & + \\
\hline Snails & - & - & - & - & - & - & - & - & - & + \\
\hline Slugs & - & - & - & - & - & - & + & - & - & - \\
\hline
\end{tabular}


subsequently moved to the greenhouse. The presence of onion thrips was recorded on the chives while the chives were still in the field.

The predatory mite Amblyseius cucumeris (Oudemans 1930) was introduced as a preventative measure against the thrips. As the numbers of thrips found on the yellow sticky boards grew, predatory hemipteran insects from the genus Orius were additionally introduced.

\section{The Hemiptera: Aleyrodidae}

Trialeurodes vaporariorum (Westwood 1856) was encountered in large numbers in the studied greenhouses: as many as 50 individuals were found on a single plant. However, the species settled solely on Rosmarinus sp., probably due to the fact that Rosmarinus sp. stayed in the greenhouse for a prolonged period of time (about 8 weeks). The development of one generation of that species typically took about a month (Goszczyński 1988). Adult individuals were caught on the yellow sticky boards. In order to combat the larva of that hemipteran insect, the parasitic hymenopteran species Encarsia formosa Gahan 1924 and the predatory mite Amblyseius swirskii Athias-Henriot 1962 were introduced.

\section{The Auchenorrhyncha}

Representatives of the genus Eupteryx were encountered in greenhouses all year round, on the herbs from the family Lamiaceae: $M$. officinalis, $M$. arvensis, $M$. xpiperita, and Rosmarinus sp. While doing research, Nast (1972; 1987) reported similar data regarding the species of the genus Eupteryx. The highest numbers of Eupteryx individuals were found in mother planted fields, from where they were probably transferred to greenhouses together with rosemary seedlings. Only individual specimens were found in the greenhouses. Adult individuals were eliminated from the mother plantings with the aid of a vacuum cleaner. The number adult individuals were also reduced by spraying the plants with natural Pyrethrum obtained from dried and crushed flowers of plants from the family Asteraceae.

Earlier studies had also reported the presence of T. vulgaris and M. officinalis, auchenorrhynchan species representing the genus Eupteryx, in the field (Goszczyński and Cichocka 2004). The insects might fly onto the inspected mother plantings from the field or might be brought to the greenhouses together with culinary herbs.

Auchenorrhynchan insects of the genus Eupteryx are an important group of pests from a financial point of view. In Great Britain, the presence of Eupteryx melissae Curtis 1837 has been reported in greenhouses on such herb species as: green sage, golden marjoram, lemon basil, and rosemary. As for Eupteryx aurata (Linnaeus 1758), it has been found on spearmint (Bennison 2001). Furthermore, Rung et al. (2009) have reported large numbers of Eupteryx decemnotata Rey 1891 on Rosmarinus sp. According to Nickel and Holzinger (2006), host plants of E. decemnotata include S. officinalis, Nepeta xfaassenii, and Rosmarinus officinalis L. as well as other species from the Lamiaceae family.

\section{Aphids}

Aphids constituted the most numerous group of species encountered on the studied plants. The aphids were divided into two groups. The first group included the species that could be found throughout the year in cultivations: Myzus persicae Sulzer 1776, Aphis gossypii Glover 1877, Aulacorthum solani Kaltenbach 1843, and Ovatus mentharius (van der Goot 1913). The second group included the species that could be found only periodically, during spring and autumn migrations: Cavariella aegopodii (Scopoli 1763), Dysaphis crataegi (Kaltenbach 1843), and Aphis fabae Scopoli 1763.

In order to reduce the numbers of aphids, the parasitic hymenopteran species Aphidius colemani Viereck 1912 was introduced, as well as Aphidius ervi Haliday 1834, Aphidius matricariae Haliday 1834, and predatory green lacewings of the genus Chrysopa. Apart from that, alate female aphids were caught on the yellow sticky boards.

The most frequently recorded species was M. persicae. It was found on E. sativa, M. xpiperita, and O. basilicum. Depending on the host plant, M. persicae varied with respect to body size and colour, ranging from pale yellow to dark green or even pink. The M. persicae aphid species is a polyphage, often encountered in various field and greenhouse cultivations (Blackman and Eastop 2000; 2006; Cichocka 1980; 1998).

The smallest aphid species, A. gossypii, was also frequently encountered. It inhabited Rosmarinus sp. and $P$. crispum throughout the year. This aphid species is polyphagous, developing in greenhouses all year round. This small aphid species comes in a variety of colours (Blackman and Eastop 2000; 2006; Cichocka 1998). In summer it may leave greenhouses and forage on the $\mathrm{Cu}-$ curbitaceae, but in the autumn it returns to greenhouse cultivations (Cichocka 1998).

Aulacorthun solani settled on the tops of O. basilicum and within 10 days was able to form numerous colonies (up to 50 individuals per plant). However, only about $2 \%$ of the total number of plants were inhabited by that species and they were instantly removed from the gutters and destroyed. The species is a polyphage and it also hibernates in greenhouses, settling on many plant species (Blackman and Eastop 2006; Cichocka 1998).

Ovatus mentharius settled only on M. xpiperita, and over a short period of time formed numerous colonies on the plant. This aphid species is classified as holocyclic and monoecious (Szelegiewicz 1968). The species had not been encountered in a greenhouse before, but introducing cultivations of its host plant into greenhouses, seemingly enabled the species to forage throughout the year. Its bionomy was thus changed; no winter eggs and continuous parthenogenetic development. Previously, O. mentharius had been recorded on peppermint in field cultivations (Goszczyński and Cichocka 2004). It might possibly fly from the field cultivations with $O$. mentharius to mother plantings and greenhouses.

The mass appearance of $C$. aegopodi on Anethum graveolens was observed in May. This was the migration period of this species from willows to plants of the parsley family (Blackman and Eastop 2000). Cavariella aegopodi was the only species that was quickly able to settle on $100 \%$ of the 
dill plants. As long as the aphids were not very numerous, they were brushed off before the herbs were taken away for sale. Those plants inhabited by a high number of insects were destroyed. So far, no other insect species apart from aphids has been encountered on dill. Large numbers of $C$. aegopodi have been encountered on herbs of the parsley family in the fields (Goszczyński 1998) as well as on dill cultivated in gardens (Cichocka 1984).

Similarly to the species discussed above, D. crataegi appeared in the spring, during its migration from hawthorns to plants from the parsley family. In the inspected greenhouses it settled on leaf stems of P. crispum. It was rarely encountered though, and found only in low numbers.

Aphis fabae appeared on P. crispum in September and formed comparatively numerous colonies (about 10 individuals per leaf base). However, the total number of plants inhabited by that species did not exceed $1.5 \%$. Aphis fabae, like M. persicae, is a polyphage and it can be encountered on many cultivated plants in the field, on ornamental plants, and even in orchards (Blackman and Eastop 2000; 2006; Cichocka 1980).

\section{Moths}

On $M$. arvensis, M. xpiperita, and O. basilicum, low numbers of the Hadeninae (Noctuidae: Hadeninae) larvae were found in the summer. In every case, several larvae were collected that had bitten out holes at the base of a plant. Adult individuals that invaded the cultivations by flying in, were caught in light traps at night. The Hadeninae are a very numerous moth family (Studziński 1979). Some of their representatives are well-known pests in those greenhouses with tomato cultivations (Napiórkowska-Kowalik and Gawłowska 2009).

In field cultivations of $A$. schoenoprasum (young seedlings), larvae of moths representing the genus Agrotis (Noctuidae: Noctuinae) damaged plant bulbs. Adult individuals of those species were also caught in light traps.

\section{True flies}

Among true flies, representatives of the family Sciaridae were the most common. They were found in the soil in which all of the studied herbs grew. In order to prevent them from appearing in high numbers, the sowing of herbs was accompanied by the introduction of parasitic nematodes of the genus Steinernema. At the time when the root system was developing, predatory mites of the genus Hypoaspis were added as well. The mites fed on the larva of dark-winged fungus gnats and on the nymphs of thrips.

True flies from the family Sciaridae are either introduced into greenhouses together with substrates (larvae) or the adult individuals fly into the greenhouses during the vegetation period. The larvae feed on the substrate, but when the substrate becomes too dry and when the larvae are too numerous, they damage root collars, roots and sprouts of plants (Szwejda 2004a, b).

On the algae, which also appeared from time to time, Scatella stagnalis from the family Ephydridae was discovered. Even though the species did not have much significance from the point of view of the monitored cultivations, its representatives often fell into the eyes of greenhouse staff and caused eye irritations. When they appeared in high numbers and settled on the cultivated plants, they sometimes polluted the leaves with small clods of black faeces. Scatella stagnalis is considered a pest of plants cultivated under covers (Dankowska 1998; 2006). According to Dankowska (2006), this fly species achieves its peak of abundance in May.

\section{Snails and slugs}

On Rosmarinus sp. growing in greenhouses, some 3 $\mathrm{mm}$ long snail specimens were observed. They crawled over plants and fed on leaves, biting out small holes in them. In mother plantings of M. xpiperita, young stages of slugs, not exceeding the size of $1 \mathrm{~cm}$ were observed. The slugs gathered at the base of plants and bit out small holes in the plants. Parasitic nematodes Phasmarhabditis hermaphrodita (A. Schneider 1859) were introduced in order to combat them. According to common belief, slugs are more harmful than snails. They significantly damage agricultural cultivations, as well as garden cultivations under covers (Kozłowski 2010). Kozłowski (2010) provided a list of domesticated plants on which slugs were likely to settle, but most culinary herbs were not mentioned. The author only pointed out that slugs settled in large numbers on Petroselinum sp. and on A. schoenoprasum, but on the latter plant species they were less numerous (Kozłowski 2010).

\section{CONCLUSIONS}

No previous research has been conducted into invertebrates that settled on culinary herbs in greenhouse cultivations. Cultivation of culinary herbs under covers, differs from vegetable cultivations, especially with respect to the length of the period that the plants spend in the greenhouse. Vegetables take many months to grow, whereas in the case of culinary herbs the period of growth is just several weeks long. For this reason, insects do not have time to form abundant populations on the herbs, but their presence still contaminates the herbs. In the case of culinary herbs, practically the whole plant is eaten, not only its fruits. Hence, the presence of even individual invertebrates in undesirable. And in the case of culinary herbs grown for sale, certainly no invertebrates can be tolerated. Obviously, no one is willing to buy herbs with aphids or snails. Infested plants have to be destroyed which results in losses for producers. Despite the implementation of biological methods of pest control, light traps, and vacuum cleaners for catching flying insects, $2 \%$ or more of cultivated plants have to be removed from greenhouse gutters and destroyed.

The culinary herbs that turned out to be the most popular with pests were the following: peppermint (representatives of six groups of invertebrates: Thysanoptera, Eupteryx sp., M. persicae, O. mentharius, larvae of Hadeninae, larvae of Sciaridae, Gastropoda), and rosemary (representatives of six groups of invertebrates: Thysanoptera, Trialeurodes vaporariorum, Eupteryx sp., A. gossypii, larvae of Sciaridae, Gastropoda), followed by basil (representatives of four groups of invertebrates: Thysanoptera, 
M. persicae, A. solani, larvae of Hadeninae, larvae of Sciaridae) and parsley (larvae of Sciaridae and three aphid species: A. gossypii, D. crataegi, A. fabae). On the remaining herbs just single invertebrate species were found.

It should be noted, that garden mint was very rarely infested with pests. Even if pests were recorded, just several individual specimens were found. Pests were noted when pots of peppermint were in close proximity to garden mint. Thus, the cultivation of peppermint in the inspected greenhouses was discontinued and only garden mint cultivations were retained.

Out of 16 species of culinary herbs cultivated in the inspected greenhouses, no invertebrates were found on 6 species, namely: Anthriscus sp., C. sativum, A. dracunculus, O. majorana, O. vulgare, and S. officinalis. The most numerous group of pests were the hemipteran insects (Hemiptera), with aphids being the most numerous within the group. But because of the specific character of the studied cultivations (3-8 weeks spent in a greenhouse), representatives of that group did not achieve high numbers and did not settle on more than $10 \%$ of plants. The only exception was $C$. aegopodii, which migrated from willows to plants from the parsley family in May and was able to settle on $100 \%$ of those plants. Apart from that period, C. aegopodii was absent from the monitored greenhouses. We believe that it would be advisable to resign from cultivating dill during May, especially since dill can be harvested from field cultivations in May. Some species of invertebrates are transferred to greenhouses from mother plantings and some fly in from the fields. True flies, snails, and slugs are often brought in together with a substrate.

The only acceptable substance that can be used for reducing the numbers of invertebrates on culinary herb cultivations is natural Pyrethrum. The cultivations can also be protected by using biological pest control which is implemented as well in greenhouse cultivations of vegetables and ornamental plants. An untypical method applied in greenhouses is the use of light traps to catch nocturnal moths such as the Hadeninae. The original method consists in using vacuum cleaners to suck out adult individuals of the Auchenorrhyncha. This method also proved effective in eliminating a small number of alate forms of other hemipteran insects and thrips. Furthermore, yellow sticky boards were hung out in the inspected greenhouses to monitor the appearances of the auchenorrhynchan insects, thrips, whiteflies, aphids, dark-winged fungus gnats, and shore flies.

\section{REFERENCES}

Bennison J. 2001. Protected herbs: Control of glasshouse whitefly and leafhoppers within IPM programmes. http://www. hdc.org.uk/project/protected-herbs-control-glasshousewhitefly-and-leafhoppers-within-ipm-programmes-4 [Accessed: April 15, 2013].

Blackman R.L., Eastop V.F. 2000. Aphids on the World's Crops. John Wiley \& Sons, Chichester, England, 414 pp.

Blackman R.L., Eastop V.F. 2006. Aphids on the World's Herba- ceous Plants and Shrubs. Vol. 1 and 2. John Wiley \& Sons, Chichester, England, 1439 pp.

Cichocka E. 1980. Mszyce roślin sadowniczych Polski. PWN, Warszawa, 119 pp.

Cichocka E. 1984. Cykle roczne i wpływ mszyc na rośliny żywicielskie. Wyd. SGGW-AR, Warszawa, 86 pp.

Cichocka E. 1998. Overwintering sites for aphids. Aphids and other Homopterous Insects 6: 17-22.

Dankowska E. 1998. Scatella stagnalis - potencjalny szkodnik roślin szklarniowych. Zesz. Prob. Post. Nauk Rol. 461: 171-176.

Dankowska E. 2006. Dynamics of occurrence of Scatella stagnalis in aeroponic tomato culture. [Dynamika występowania brzegówki (Scatella stagnalis Fallen) w aeroponicznej uprawie pomidora]. Prog. Plant Prot./Post. Ochr. Roślin 46 (2): 406-408.

Fauna Europaea 2012. Fauna Europaea version 2.5. http://www. faunaeur.org. [Accessed: May 30, 2013].

Goszczyński W. 1988. Biologiczne podstawy integrowanego zwalczania mączlika szklarniowego (Trialeurodes vaporariorum Westw.). Wyd. SGGW-AR, Warszawa, 124 pp.

Goszczyński W. 1998. Hemiptera infesting umbelliferous and spice medicinal plants. Aphids and other Homopterous Insects 6: 31-34.

Goszczyński W., Cichocka E. 2004. Aphids on selected seasoning and medicinal herbs. Aphids and other Hemipterous Insects 10: 15-22.

Kozłowski J. 2010. Ślimaki nagie w uprawach. Klucz do identyfikacji. Metody zwalczania. IOR - PIB, Poznań, 63 pp.

Napiórkowska-Kowalik J., Gawłowska J. 2009. Harmfulness increase of tomato moth [Lacanobia oleacea L. Lepidoptera, Noctuidae, Hadeninae] on glasshouse tomatoes (Lublin Region). [Szkodliwość piętnówki brukwianki (Lacanobia oleracea (L.) Lepidoptera, Noctuidae, Hadeninae) na pomidorach uprawianych w szklarniach w okolicach Lublina]. Prog. Plant Prot./Post. Ochr. Roślin 49 (4): 1723-1727.

Nast J. 1972. Palaearctic Auchenorrhyncha (Homoptera). An annotated check list. Polish Scientific Publishers, Warsaw, 550 pp.

Nast J. 1987. The Auchenorrhyncha (Homoptera) of Europe. Ann. Zool. 40 (15): 535-661.

Nickel H., Holzinger W.E. 2006. Rapid range expansion of Ligurian leafhopper, Eupteryx decemnotata Rey, 1891 (Hemiptera: Cicadellidae), a potential pest of garden and greenhouse herbs, in Europe. Russian Entomological Journal 15 (3): 295-301.

Rung A., Halbert S.E., Zielsk D.C., Gill R.J. 2009. A leafhopper pest of plants in the mint family, Eupteryx decemnotata Rey (Hemiptera: Auchenorrhyncha: Cicadellidae), Ligurian leafhopper, new to North America. Insecta Mundi 0088: 1-4.

Studziński A. 1979. Piętnówki w Polsce. PWN, Warszawa-Poznań, 189 pp.

Szelegiewicz H. 1968. Katalog fauny Polski. Mszyce - Aphidodea. PWN, Warszawa, 316 pp.

Szwejda J. 2004a. Ochrona warzyw przed ziemiórkami. Hasło ogrodnicze 7. http://www.ho.haslo.pl/article.php?id=1789 [Accessed: April 17, 2013].

Szwejda J. 2004b. Ziemiórki - szkodniki upraw pod osłonami. Owoce, Warzywa, Kwiaty 16: 30. 